In some constitutions the iodide of potassium frequently taken, even in medicinal doses, proves speedily injurious. It produces a diseased condition, to which the name of "iodism" has been given. In one instance, three grains, taken three times a day, caused, after the fourth dose (twelve grains), shivering, headache, thirst, quick and full pulse, with vomiting and purging. In another case a dose of five grains caused difficulty of breathing, discharge from the eyrs and nostrils, inflamed conjunctiva, and most of the symptoms of a severe cold, for which these injurious effects of the iodide may be easily mistaken. In some cases the iodide has acted powerfully on the salivary organs, causing salivation. In others it has acted powerfully on the kidneys, and has produced a copious flow of urine. These facts show that it is not a medicine which can be safely taken in quantities of sixteen grains daily by a person who is not under medical observation.

The sale of medicines of this kind should be strictly prohibited, unless the bottles containing them were supplied with a caution label setting forth their true composition. It is only reasonable that a person should know what he is purchasing; but the rule of English law applied to such cases is the same as in the buying of a horse, Caveat emptor. A man who has reached adult age is supposed to be able to exercise a sound judgment for himself, although it is notorious that there is no instance in which so much credulity is shown as in the purchase of medicines to which some great curative powers are attributed.

AlFrec Swaing Tayior, M.D., F.R.S., Lecturer on Medical Jurisprudence and Toxicology in Guy's Hospital.

St. James's-terrace, Regent's-park, July 15 th, 1875

\section{ON THE PHYSICAL CAUSE OF THE PRESYSTOLIC MURMUR.}

To the Editor of THE LANCET.

SIR,-I should deem it almost impossible for anyone with an unbiased mind, a correct ear, and an adequate experience to have failed repeatedly to verify the accuracy of Dr. Gairdner's description of the presystolic murmur had we not a few such distinguished instances to the contrary. It is true that this murmur is a difficult one to demonstrate for the first time to many, even of those who can distinguish most of the morbid heart sounds readily. The exceeding sharpness and rapidity with which the first sound succeeds the murmur leads many to regard the murmur as systolic, and to mistake the first for the second sound of the heart. In other cases, again, I have known the murmur to be mistaken for a diastolic bruit. But having once mastered a case, the murmur is a very easy one to recognise when not complicated by the presence of others. The term auricular systolic, used by Dr. Gairdner, is not, however, I venture to think, quite a happy one, inasmuch as it does not describe the whole mechanism of the murmur. It is true that in most cases a bruit is only audible with the accelerated passage of blood through the narrowed mitral orifice during auricular systole. But both thrill and murmur may commence before the time of the auricular systole, "extending from the second sound through the pause." Dr. Gairdner spealss of this as an associated murmur, the noise of the blood stream attracted towards the expanding ventricle. It is, however, as far as I know, peculiar to cases of mitral stenosis, being prolonged and intensified up to the systole by the contraction of the auricle. The current of blood propelled during the pause by the residual force of the ventricular contraction may, as I think Dr. Salter has pointed out, in certain cases of mitral constriction (especially in the funnel-shaped mitral) be sufficient to set the valve vibrating, and to give rise to a continual bruit extending from the second sound through the pause to the first, and being augmented by the increased tension of blood when the auricle contracts. Since, then, narrowing of the mitral orifice is the only condition necessarily present at all periods of the murmur, I think the older terms mitral-constrictive or presystolic preferable to that proposed by Dr. Gairdner.

I am, Sir, yours faitbfully,

R. Dovgras Powels, M.D., F.R.C.P.,

Physician to the Hospital for Consumption and Diseases of the Chest July 19th, 1875.

\section{"PASS" AND "PLUCK" AT THE COLLEGE OF SURGEONS.}

To the Editor of THE LANCET.

SIR,-I think it would have been fairer to the various medical schools if the report of the examiners, which was published last week, had been supplemented by another set of statistics, showing the number of registered students at each school who have completed the studies required for the primary and pass examinations respectively.

I have had the curiosity to place in parallel columns(1) the number of students at the various metropolitan schools who registered for the first time in October, 1873, and who therefore should have been candidates at the primary examinations in April and May last; and (2) the number from each school actually examined during the whole year:-

\begin{tabular}{|c|c|c|c|c|}
\hline & & $\begin{array}{l}\text { No. of First-year } \\
\text { Students regis- } \\
\text { tered in } \\
\text { October, } 1873 .\end{array}$ & & $\begin{array}{l}\text { No. of candidates } \\
\text { at Primary } \\
\text { Examination in } \\
\text { in 1874-75. }\end{array}$ \\
\hline St. Bartholomew's & $\cdots$ & 100 & $\ldots$ & $80 \cdot 83$ \\
\hline Guy's & $\cdots$ & 94 & $\ldots$ & 78 \\
\hline University College & $\ldots$ & 66 & $\ldots$ & 87 \\
\hline St. 'Thomas's ... & $\ldots$ & 53 & $\ldots$ & $64: 3$ \\
\hline King's College ... & $\ldots$ & 46 & $\ldots$ & 47 \\
\hline Middlesex $\quad \ldots$ & $\ldots$ & 37 & $\ldots$ & $26 \cdot 5$ \\
\hline St. Greorge's & $\ldots$ & 34 & $\ldots$ & $31 \cdot 5$ \\
\hline London ... & $\ldots$ & 38 & $\ldots$ & 41 \\
\hline St. Mary's & $\ldots$ & 21 & $\ldots$ & $25 \cdot 5$ \\
\hline Charing-cross ... & . & 13 & $\ldots$ & $13 \cdot 5$ \\
\hline Westminster ... & .. & 12 & $\ldots$ & 10 \\
\hline
\end{tabular}

It is obvious from this list that the residuum of students who have been kept back from the primary examinations is much greater at some schools than at others, and this consideration materially modifies any estimate that is made of the relative merits of the teaching of anatomy and phrsiology.

I remain, Sir, yours very faithfully,

\section{CONTAGION OF PUERPERAL PY ÆMIA.}

To the Editor of The LANCET.

SiR,-I observe in your issue of this day (July 17th) that my friend Dr. Fordyce Barker represents me as holding that what is called "puerperal fever" is not contagious. You will give me space to correct this error of his. I not only have never said that it is not contagious, but $I$ have said it is " communicable," or, in ordinary language, contagious. I am, Sir, your obedient servant,

Edinburgh, July 17th, $1875 . \quad J$. MatTrews DUNCaN.

\section{A FRAUD PREVENTED. To the Editor of THE LANCET.}

SIR, - In one of your recent numbers there is an advertisement asking for a gentleman who has recently passed the L.R.C.P. Exam. of London, to prepare a gentleman for the two examinations for that qualification, and offering a fee of 250 . I answered this advertisement, and have to-dav received a reply to my letter. To save your space, I may say that the first part of this letter states where the writer of it was educated, and expresses a fear lest he should be unable to pass the examinations by September, when he has to go abroad. Then follows the pith of the letter, which $\mathrm{I}$ give in full and verbatim:-

"Now, Sir, a few words in strictest confidence. If you will present yourself and pass the first and second Royal College of Physicians Examination of Edinburgh (where I am unknown), I will give you the sum of $\$ 50$, exclusive of traveling (sic) and boarding expenses for three days, while the examination lasts. Will meet you at * * * *, and accompany you to Edinburgh, and pay the $\& 50$ in any way you mention. Exam. on the 28th of this month, or special."

Nothing but an urgent sense of duty would lead me to publish a letter sent to me in "strict confidence," but secrecy in this case would be participation in a fraud. I cannot conceive that any good can arise from publishing 
this gentleman's name. I have sent a copy of his letter to the College of Physicians of Edinburgh, and will forward the name to any of the examining boards of the United Kingdom who apply to me for it.

I am, Sir, your obedient servant,

Gower-street, Bedford-square, w.c. A. Pearce Gould, B.S.

\section{PARIS.}

(From our own Correspondent.)

THE death of Demarquay has been the chief medical topic of the last week, and very many anecdotes touching this eminent surgeon have been related in conversation or published in the journals. Some of his bequests have already been made known. Thus he leaves 100,000 francs to the Academy of Medicine, to be employed either in helping that learned body to select a more suitable place of residence, or in founding an annual prize. In like manner 10,000 francs have been left to the Société de Chirurgie, for founding a triennial prize. His library, which was exceedingly extensive and complete, has been bequeathed to the Maison Municipale for the use of the medical men and students attached to the hospital. His former pupils have inherited his surgical instruments. Besides these scientific and professional bequests, there are others which denote the humanity and religious disposition of Demarquay. Thus certain sums of money have been left to ameliorate the condition of the curate, the sister of mercy, and the village teacher of Longueval, Demarquay's birthplace; 15,000 francs to the poor; 10,000 francs for the charitable institutions of Longueval, \&c. It is said that Demarquay's brother inherits all the rest of his fortune, consisting of 800,000 franes, and his fine property of Longueval. But perhaps there is some exaggeration in this estimate of Demarquay's fortnne, though he was said, especially during the latter years of his life, to make a yearly income of $£ 6000$ by his practice.

In connexion with the floods which have produced such destruction in the south, and spread a general feeling of consternation throughout this country, it is well to mention the proofs of humanity and generosity which have been given by the profession. Besides the invaluable services rendered by the medical men of Toulouse and the other localities to the victims of the floods, the presence of mind and noble behaviour of two internes (house-surgeons) of the Hôtel Dieu of Toulouse deserve to be especially noticed, they having been the means of saving the lives of the inmates of the hospital, more than 200 in number. On June 23rd, at 5 P.M., the waters of the Garonne had invaded the Faubourg Saint Cyprien, and had filled the cellars, kitchens, and pharmacy of the Hôtel Dieu. The whole hospital was disorganised. The servants and patients were helpless from terror. The flood was still rising. The only bridge left, the one opposite the Hôtel Dieu, was threatened with destruction. The general in command had ordered his troops to retire. The wards of the hospital were beginning to be reached by the water, the building began to crack and shake, and every means of communication with the town was cut off. Under these most trying and extraordinary circumstances, MM. Bonneau and Labat, the house-surgeons, took a rapid determination, and, assuming all the responsibility, they decided that the hospital should be evacuated by any means. Owing to their energetic exertions, the 200 patients were conducted or carried safely out of the hospital and over the bridge, amidst the greatest anxiety and the most painful incidents. Two days after, when Marshal Macmahon visited the flooded city, the Prefect presented the two gallant house-surgeons to him, and in the name of the city demanded for them the Cross of the Legion of Honour as a reward for their intrepidity.

The concours for appointing two vice-professors of surgery and one of accouchement at the School of Medicine is very nearly ended, the candidates now going through the last test, that of publishing, and arguing on, various theses appointed by the judges. It may be of interest to give a list of the subjects chosen by the Paris professors:-1. The infuence of constitutional maladies on the course of traumatic lesions. 2. On arthropathies of nervous origin. 3. On the accidents which may complicate traumatic dislocations. 4. Comparative study of the various methods of exercise. 5 . On the value of bysterotomy in the treatment of fibrous tumours of the uterus. 6. On the part played by muscular action in traumatic luxations. 7. Pathogeny, course, and termination of tetanus. 8. On transfusion of blood. 9. Point out the influence which histology has exercised on the progress in diagnosis of tumours. 10. Traumatic lesions of the liver. 11. On the various dispositions of the funis, except procidentia, which can disturb the regular course of pregnancy and parturition. 12. Make known the counter indications of version in presentation of the shoulder, and the means which can be used to supersede this manœuvre. 13. In what cases is it necessary and advisable to procure abortion. All these various theses, after having been printed, will be put in the hands of the various candidates, each one of them having to defend his thesis against two adversaries.

Paris, July 13th, 1875.

\section{attedical âfelos.}

Royal College of Physicians of London. The following gentlemen were admitted licentiates on the 19th inst. :-
Anningson, Thirkell, Burnley.
Baly, William, St. Mark's Hospital, City-road.
Blackmore, George Heury, Shaftesbury-road, Hammers nitb.
Childs, Christopher, Warwick-street.
Clarke, Arthur, Brill, Buckinghamshire.
Clayton, Joseph Everett, Rutland-street.
Collins, Charles Edward, Crowndale-road.
Cooper, Ernest Frederie, St. Paul's-road.
Haines, Edmund William, Tavistock-place.
Hood, Francis Edward Charles, Guy's Hospital.
Irving, Charles, St. Bartholomew's Hospital.
Jackson, Ernest Carr, Harley-street.
Kebbell, William, Brighton.
Kempe, John Arthur, Wimpole-street.
Murrell, William, York-street, St. James's-square.
Pasley, Nicholas Claude Burgoyne, Palace-road.
Peck, Awdry, Yalding, Kent.
Peevor, George Hamilton, Portsdown-road.
Phillips, Arthur Owen Henry, Bethlem Hospital.
Poynder, George Frederick, Weeting, Brandon.
Ree, Frederick George, Ealing.
Reid, Thomas Whitehead, St. Bartholomew's Hospital.
Rendall, John, Maiden Newton, Dorchester.
Robson, Arthur William Mayo, Leeds.
Romano, Frederick William Richard, Albany-rcad.
Rudd, Leonard, Gug's Hospital.
Spooner, Frederick Henry, Plymouth.
Thompson, Alfred, Spilsby.
Waylen, Greorge Swithin Adee, Granville-square.
Williamson, Francis, Durham-place.

Rotal College of Surgeons of England. The following gentlemen, having passed the required ezaminations for the diploma, were duly admitted Members of the College at meetings of the Court of Examiners on Tuesday and Wednesday last:-

Alford, George E., Weston-super-Mare.

Blake, Andrew Henry, L.S.A., Castle-street Erst.

Briggs, William H., Stroud, Gloucestershire.

Chippingdale Samuel Dodd Commercial-road

Clayton, Joseph Everett, L.R.C.P. Lond. Leeds.

Clinton, Samuel A. M.D. L.S.A. Chislehurst, Kent.

Crouch, Ermest I., L.S.A., Hornton-street, Kensington.

Daubeny, Charles A., Yatton, Somerset.

Eames, James Crompton, M.B. Edin., Manchester.

Gawith, James Crompton, M.B. Edin., Man

Haines, Edmund W., L R.C.P. Lond., Tavistock-place.

Hayward, William 'T., L.K.Q C.P. Irel., Liverpool.

Hobson, Lewis John, Ainger-terrace.

Hood, Francis E. C., L.R.C.P. Lond., Bletchingley, Surrey.

Hunter, Robert H. A., Dalston.

Irvine, Delaware Lewis, Newcistle.

Jones, Thomas R., L.R.C.P. Lond., Walton, Lancashire.

Jumeanx, Benjamin, L.R.C.P. Edin., Stafiord.

Latour, George Lewis, Lambeth.

Lumby, John R. H., Birmingham.

Mitchell, Charles J C., L S.A., Bedford.

M'Naught, James, M.B. Edin., Wall, Northumberland.

Ormerod, J oseph Arderne, Oxford.

Palmer, Francis C., Weston-super-Mare.

Peevor, George Hamilton, L.R.C.P.Lond., Portsdown-ro $3 d$

Richards, Thomas, Cardiff

Skipworth, Herbert, Brigg, Lineolnshire.

Smith, Charles Callow, L.S.A., Redditch.

Sparrow, George Gordon, I.R.C.P. Edin., Southsea.

Street, Alfred W. F., Barnetby, Lincolnshire.

Sylies, William, L.R.C.P. Edin Sheffield.

Symunds, Charters J., St. John's, New Brunswick, Canada. 